\title{
1. Mapping industrial and territorial dimensions for the design of place-based innovation policies: the rationale of the book
}

\author{
Roberta Capello, Alexander Kleibrink and \\ Monika Matusiak
}

\subsection{MAPPING INNOVATION AS A RECENT NEED FOR THE DESIGN OF POLICY: AIM OF THE BOOK}

Smart specialisation is now a well-known strategy of the European Union (EU), due to its implementation in the 2014-2020 period to boost the competitiveness of Europe and its regions. Prior to this, innovation activities were related primarily to research and development (R\&D) expenditure. Smart specialisation aimed to change this, by embracing a much larger concept of innovation, insisting on the idea that entrepreneurial discovery was not based only in high-tech industries and in R\&D activities. The one-size-fits-all policy of the Lisbon and Europe 2020 agenda was totally replaced, and the idea that innovation strategies had to be place-based (Barca, 2009), as a result of bottom-up processes based on the selfdiscovery of entrepreneurial capability, drove the present programming period 2014-2020 (Giannitsis, 2009; Foray, 2009; Foray et al., 2009).

The new policy strategy was therefore calling for an attempt to supersede the old innovation policy style, based on centralised planning methods for the identification of industrial development priorities. The new strategy was aiming to ensure the appropriateness of the logic and design of the policy, as well as the relevance of the local context, rather than this being imposed by an external (supra-regional) body, as with a place-based policy à la Barca (Barca, 2009).

In addition to this redirection of innovation policy style, smart specialisation was asking for the identification of priorities, a policy prioritization capable of boosting growth, since it is based on regional 
context conditions. As one of the founding fathers of smart specialisation, Dominique Foray claimed that contemporary innovation strategies ought to be 'largely about the policy process to select and prioritize fields or areas where a cluster of activities should be developed, and to let entrepreneurs discover the right domain of future specialization' (Foray et al., 2011, p. 7).

The new approach towards innovation policies was well received by scientists and experts, since it was interpreted as being based on innovative, modern and shareable principles. They viewed it as a cultural leap in the design and implementation of innovation (and competitiveness) policies, moving away from an R\&D-based policy that over past years has demonstrated all its fragility and inefficiency (Capello and Kroll, 2016).

However, as with all paradigmatic changes, the implementation of this policy model was much more complicated than expected (Capello and Kroll, 2016; Camagni and Capello, 2020). Most notably, the achievement of its goals - mainly the identification of the 'smart domain' in which to look for and encourage an entrepreneurial discovery - emerged as the primary difficulty in the implementation of the new strategy, as the first evaluations of the strategy highlighted (Iacobuci and Guzzini, 2016).

In particular, place-based innovation policy design requires an in-depth understanding of territories and their complexity. Traditional statistics, with low public availability of data at disaggregated (sub-sectoral and regionalised) level, often do not provide enough information. Therefore, new methods and approaches are called for by scientists and experts that can inform decision-makers and stakeholders in choosing priorities and directions for their innovation strategies. The 'mapping' of innovation, of its modes, features, potentialities, is a fundamental tool for providing policy-makers with the right information on which to build a smart innovation strategy.

This book provides new reflections on the conceptual approaches for the identification of innovation priorities, the data required, the methods with which to turn data into useful information, and the mapping of the information available. On the conceptual side, new reflections have been launched on the concept of innovation itself. On the empirical and methodological side, new technologies have made it easier and cheaper to gather and process massive and novel kinds of data. On the policy side, legislation and soft regulation is increasingly defining how evidence should be used to design development policies.

This book builds on the experience of more than 100 innovation strategies for smart specialisation which regional and national governments have designed in the EU since 2012. In what one of the leading industrial relations scholars, Charles Sabel, has labelled 'the biggest experiment in 
innovation and industrial policy' in the world, mapping various dimensions of the innovation system was a critical and legally required element.

The book presents four basic dimensions of mapping for innovation policies and how they can be meaningfully combined and complemented. It shows how the economic, scientific, innovation and societal potential of cities, regions and countries can be measured, and how these insights can inform policy-making. Mapping is understood as a quantitative analytical exercise using available data presented at the territorial (sub-national) level.

Mapping methodologies and techniques are the tools that policymakers and innovation analysts use to design appropriate policies for different contexts and development levels of countries and their regions. Numerous methods and data sources can be useful in meeting the growing interest in the evidence-base of the numerous facets of innovation policies. Which methods governments and analysts ultimately use to justify choices and investments depends on the level of socio-economic development, the policy objectives and their analytical capabilities. This book provides a comprehensive menu of options that are applicable to both emerging economies and Organisation for Economic Co-operation and Development (OECD) countries, albeit with different degrees of suitability. While each territory has its own unique characteristics, recent developments in analytical techniques enable us to collect new data and link them in novel ways. The book shows how to reap these potentials to deal with economic and societal challenges, in both dynamic metropolitan and remote rural areas. Mapping the socio-economic fabric of territories contributes to better innovation strategies by bringing together the pieces that make up effective innovation systems and providing a strong evidence base for informed decisions.

This book pays strong attention to the preparation of 'knowledge bases' for policy discussions and their uptake by practitioners. To do this, the book considers 'what if' type approaches that reflect on a number of potential options, discussing 'holes and gaps' and thus pushing for experimenting with different methods for different purposes. Uniquely, this book considers innovation:

- As requiring a policy design and evidence base to be developed in a way which leads to successful competitive strategies.

- As place-based. It is contingent on spatially clustered socio-economic activities and actors, and therefore all methods presented pay attention to this spatial dimension.

- As based on the sectoral dimension. Increasingly attention is paid to developments inside and across economic sectors. Yet to date no 
systematic book has discussed this at a sufficient level of detail. Only a sectorial and cross-sectorial picture allows us to see how different industries develop and link over time.

- As requiring specific information to develop innovation policies. Policy-makers should understand what is being done, as well as how and why certain phenomena are mapped. Mapping in this case is concerned with the uptake and how public administrations can employ these methods themselves.

The timing of this book is fortunate, since the design of the next generation of more than 100 innovation strategies in Europe is beginning, making it a timely and useful reference for practitioners and academics alike. Given the increasing interest in the EU's smart specialisation approach across the world, from Mexico to Australia, the book has the potential to inform discussions and policies at a larger scale.

The value added of this book lies in the presentation of new conceptual thinking, new data and methods for their interpretation. Especially, the book shows how both conceptual and methodological developments have changed the way it is possible to map interesting information for policymakers and stakeholders for sustaining place-based innovation policies.

\subsection{MODERN CONCEPTUAL APPROACHES TO INNOVATION}

In the mid-1990s, the conceptual approach to the interpretation of the innovation process became more complex. Technological change required increasing systemic knowledge and integration of different technological competences in order to produce one single product. The 'linear model' of innovation - referring to a logical sequence between creativity and knowledge, invention, innovation and economic performance - was highly criticised for its unrealistic idea that rational and orderly innovation processes could exist (Edgerton, 2004), and was replaced by a systemic approach.

The process of knowledge acquisition was supposed to be influenced by the complexity and systemic nature of innovation; it therefore was expected to call for an interactive process of new knowledge acquisition. Learning necessarily required cooperation and interaction between firms and the local scientific system, between different functions within the firm (between production and research and development, between marketing and research and development), between producers and customers, and between firms and the social and institutional structure, in either formal 
or informal ways, the former imposing interactive forms of organizational learning, the latter based on direct experience or that of others, which came about through activities focused on finding solutions to specific technological, productive or market problems.

The consequence of such cooperation and interaction was that the innovative process was strongly localised: it resulted from the variety of traditions, norms, habits, social conventions and cultural practices that constituted what has been called 'institutional thickness'. ${ }^{1}$ Innovation therefore could not be understood properly unless it was examined within the socio-cultural and institutional context in which it took place; in particular, innovation required 'institutional proximity', meaning the set of norms, codes and rules of behaviour which help economic actors (people, individual firms, public and private institutions) to adopt forms of organisation that facilitate interactive learning. 'Institutions are here defined as the sets of habits, routines, norms and laws that regulate the relations between people and thus shape human interaction and learning' (Lundvall and Johnson, 1994, p. 33).

On the basis of the systemic nature of innovation, and of the context conditions that guarantee interactive and collective learning processes, a series of theories emerged emphasising the importance of 'proximity' among innovative actors as a condition for cooperation to take place. In the 2000s, a conceptual framework was put forward where the concept of 'cognitive proximity' was emphasised as a crucial element for explaining innovation capacity. In order to create new technological solutions and new innovation, firms have to share complementary knowledge. At the same time, firms have to share a common knowledge base that guarantees a common language and mutual understanding among firms. In the literature, this condition was labelled 'related variety', and it was defined as a variety of interrelated technological solutions with a common knowledge basis. $^{2}$

This theory was recognised as a useful approach to identify a smart innovation strategy for a region. This approach, in fact, underlines that the innovation process is strongly shaped by a specific knowledge base

1 See Amin and Thrift (1994). The term 'institution' should of course be understood in the sense given to it by North's and Williamson's institutional economics, namely as a set of societal norms and 'rules of the game' (North, 1990, p. 3).

2 The first author to deal with the concept of 'related variety' was Nooteboom (2000), but it is thanks to the Dutch school of evolutionary economic geography that the concept has developed and received empirical evidence. For advanced studies on this concept, see Boschma (2005), Frenken et al. (2007), Boschma and Iammarino (2009) and Boschma et al. (2012). 
and the combinations of economic sectors in regions. A diversification of the regional innovation path is possible, but within the existing innovation trajectories and knowledge base. Existing specialisations and knowledge bases in regions provide options for diversification, but what has to be avoided by the region is the development of new economic structures from scratch (Boschma, 2014). The related variety concept has become rather useful in the identification of possible entrepreneurial discoveries within the region (Van Oort et al., Chapter 3 in this book); when empirically applied, it may become a useful tool to identify the innovative domains in which 'a region is likely to excel given its existing capabilities and productive assets' (Foray et al., 2011, p. 7).

Even if clear merits can be attributed to the related variety concept, this theory has an important intrinsic limitation, in that it reduces cognitive aspects to the industry dimension. In fact, learning processes occur within the industry, and the condition for them to occur is the simultaneous presence of a knowledge complementarity and a common knowledge basis. But this means that they occur in the same way wherever the industry is located, and therefore that the learning process is separated from the economic and territorial context (Capello, 2019).

Recently, the idea that the industrial dimension was not sufficient to explain the regional innovation capacity has been strongly advocated (Capello, 2019). When applied at regional level, in fact, the industrial logic showed two kinds of limits. The first one referred to the fact that this logic risked pushing towards the interpretation of formal knowledge as the main source of innovation; instead, a variety of informal elements, such as face-to-face meetings, informal cooperation, creativity and collective learning processes are behind a learning process. The second limit referred to the idea that only knowledge stemming from local sectors was a source for local innovation; instead, a large literature highlighted the role of knowledge coming from outside the region as a fundamental source for innovation.

In order to overcome such limits and restore the territorial elements to the centre of the explanation of innovation processes, a new concept was recently proposed: that is, regional patterns of innovation, defined as the spatial breakdown of the single, logical phases of the innovation path - from invention based on new knowledge, to innovation, ending with development - built on the presence/absence of territorial preconditions for knowledge creation, knowledge attraction and innovation. ${ }^{3}$

3 On the concept of regional patterns of innovation, see Camagni and Capello (2013) and Capello and Lenzi (2013). 
The different components of the cognitivist, linear model of innovation were broken down, separated, allocated differently in time and space, and recomposed at the end following a relational logic of interregional cooperation and exchange.

The concept of regional patterns of innovation was translated into empirics, and the identification of such patterns in the real world is extremely useful in the identification of smart innovation strategies (Capello and Lenzi, Chapter 5 in this book). In fact, as will be largely explained in Chapter 5, by grouping regions on the basis of similarities in innovation processes, a taxonomy of innovative regions can operationally serve the purpose of defining innovation pathways by preventing unlikely local strategies and undue use of public resources (Capello and Camagni, 2013; Camagni et al., 2014).

\subsection{THE EVOLUTION OF DATA ON INNOVATION}

Using data and information to design development strategies is by no means new to place-based policy-making. How to systematically gather data and analyse them has been a concern for urban and regional planning for more than a century. In the mid-19th century, Scottish town planner Sir Patrick Geddes had already pointed out the need for panel data and accompanying maps in the context of industrial development. He was acutely aware that, 'What was needed to start was an adequate collection of maps: maps describing town conditions before the industrial revolution, maps a generation later when industrial expansion was in full swing, and maps for current conditions' (Boyer, 1986, p. 72). Nowadays there is arguably a lack of neither data nor maps. The sheer amount of potentially relevant data and the increasing variety of processing techniques have likely surpassed even Geddes's expectations. The new challenge lies in deciding upon the right questions to ask about what kind of data are needed.

For industrial and later innovation policies, the guiding questions or Erkenntnisinteresse of policy-makers has changed over time. Since the 1980s it has been increasingly clear that differences between countries matter, in terms of economic structure, R\&D capabilities, institutional set-up and innovation performance. These ideas were embodied by the concepts of national innovation systems and industrial policy (Lundvall, 1992; Freeman and Soete, 1997; Piore and Sabel, 1984). This bias towards nation-states held until the 1990s when interest in intra-country diversity started to grow. In the academic and policy discourse, national innovation systems were no longer seen as monolithic and homogenous entities. 
Rather, the view that states consisted of different regional innovation systems put the territorial dimension into the limelight (Cooke, 2014; Morgan, 1997; Ohmae, 1993). Three main reasons explain this renewed interest in questions of place:

- Available data and experience indicated that regions and cities are different with respect to industrial specialisation patterns and innovation performance (Porter, 2003).

- Research on knowledge spillovers, relatedness between sectors and their role in innovation processes highlighted the importance of local interactions (Asheim, 2012; Boschma, 2017).

- On the policy side, powers to design or implement industrial and innovation policies have been increasingly devolved to regions and cities in many countries (Tödtling and Trippl, 2005).

However, many place-based economic and innovation policies have not performed as expected (Rodríguez-Pose, 2018; Barca, 2009). This is, at least in part, a consequence of their lack of attention to local conditions and history. It turned out that a vision for the future is not enough to create local economic growth, even if it is accompanied by large public investments. Robust information about the state of the local economy is necessary to identify realistic and promising avenues of development, as well as the barriers that need to be overcome and the local actors that need to be engaged. Only by having this kind of information is it possible to target local economic development policies effectively and have a proactive industrial policy for places (Foray, 2015; Hausmann and Rodrik, 2003).

The predominant emphasis on the national level, at least at the beginning, partly determined what kind of data and evidence would be used for industrial and innovation policies at the regional level. Regional analysis has been widely dependent on established industrial statistics, but a variety of new data sources are gaining recognition, and more and more analytical methods are being developed to use them. Compelling new efforts for mapping combine established industrial data (employment, firm number and characteristics, sectoral gross value added, and so on) and science, technology and innovation (STI) indicators (patents, research funding, publications, and so on) with novel open data on firms and start-ups and interaction data from digital platforms (Kleibrink and Mateos, 2017). Advances in social network analysis now make it possible to visualise large networks of companies, research institutes and universities. Figure 1.1 depicts the evolution of dominant data use over time. 


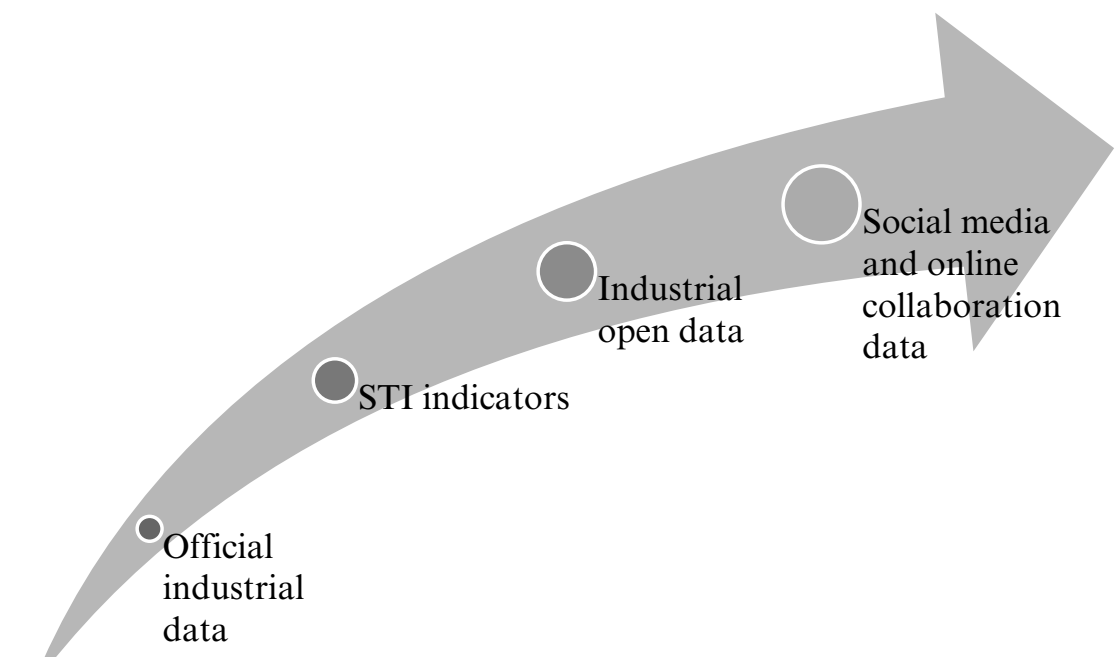

Source: Based on Kleibrink and Mateos (2017).

Figure 1.1 Evolution of data sources for place-based innovation policies

Yet how exactly was this kind of data used for innovation policy-making? European regions have been designing territorial innovation strategies over the last 25 years. In the mid-1990s, the European Commission (EC) integrated innovation support into the European Regional Development Fund (ERDF). This laid the foundation for what we understand today as 'regional innovation strategies'. Innovative actions were further developed in the period 2000-2006. In parallel, pre-accession countries in Eastern Europe benefited from similar support to develop place-based innovation strategies. In total, more than 120 regions participated in these strategy exercises (Charles et al., 2000). Since these early beginnings, learning and feedback exercises have become an inherent part of regional innovation policies (European Commission, 2007). While these initiatives brought greater levels of cooperation, transparency and expertise to regional administrations, there was little emphasis on the quality of strategy design and the robustness of data used to inform policy choices. Evaluations have indeed shown that this was one of the main weaknesses of the first generations of place-based innovation strategies. It turned out that the identification of relevant societal needs and capabilities at the beginning of strategy-making is critical. The successful cases from those years had a relatively precise idea of the region's endowments, which in turn made it 
easier to develop appropriate solutions to overcome identified bottlenecks (Socintec and Inno, 2005).

In the 1990s and 2000s, obtaining detailed data at the local and regional level was rather difficult, except for traditional industrial statistics. Nowadays, data arguably abound, at least in OECD countries. The problem is much less one of data availability, but rather of deciding what data are relevant and, as a final step, having the skills to analyse them properly. Many if not most local and regional administrations do not have sufficient competencies and resources to examine overly complex or unstructured data. Analytical capacities are often unevenly distributed across regional and local authorities, thus aggravating sound policy analysis (Borrás, 2011; Borrás and Jordana, 2016). Except for some vanguard regions such as Catalonia and Wales, most regional administrations have not developed modern open data tools to monitor local STI developments. ${ }^{4}$ This is one of the key goals of this edited volume: to inspire and explore the possibilities of new data sources and analysis for regions in Europe and beyond.

\subsection{NEW DATA FOR A NEW POLICY PERSPECTIVE: QUANTITATIVE MAPPING}

The unfulfilled expectations of place-based economic and innovation policies triggered a reflection process in the European Union. Despite large public investments, success was partial and ambiguous at best. Regional inequalities inside EU member states and globally have been on the rise (Iammarino et al., 2019; OECD, 2016). Investments were not strategic in the sense of identifying realistic and promising avenues of development. It became clear that a truly territorial policy must pay attention to local conditions and history, regional bottlenecks, and the needs and capacities of local actors who need to be engaged. To achieve this, acquiring robust information about the state of the local economy became an essential first step.

In EU policy cycles, consensus emerged that targeted local economic development policies and a proactive industrial policy needed a stronger evidence base than before (Barca, 2009). This is why the ERDF regula-

4 Catalonia's RIS3-MCAT Platform is an interactive tool visualising the development of sectorial and technological specialisations and the networks among STI organisations (http://catalunya2020.gencat.cat/en/plataforma-ris3-mcat). Arloesiadur is an open data platform developed jointly by innovation charity Nesta and the Welsh Government to map industry, research and technology networks (https://arloesiadur.org). 


\section{Table 1.1 Fulfilment criteria for smart specialisation in current and proposed EU legislation}

\begin{tabular}{|c|c|}
\hline $\begin{array}{l}2013 \\
\text { A national or regional smart } \\
\text { specialisation strategy is in place } \\
\text { that: }\end{array}$ & $\begin{array}{l}2018 \\
\text { Smart specialisation strategy shall be } \\
\text { supported by: }\end{array}$ \\
\hline $\begin{array}{l}\text { Is based on a SWOT or similar } \\
\text { analysis to concentrate resources } \\
\text { on a limited set of research and } \\
\text { innovation priorities }\end{array}$ & $\begin{array}{l}\text { Up-to-date analysis of bottlenecks } \\
\text { for innovation diffusion, including } \\
\text { digitalisation }\end{array}$ \\
\hline $\begin{array}{l}\text { Outlines measures to stimulate } \\
\text { private RTD investment }\end{array}$ & $\begin{array}{l}\text { Existence of a competent regional/ } \\
\text { national institution or body, } \\
\text { responsible for the management of the } \\
\text { smart specialisation strategy }\end{array}$ \\
\hline Contains a monitoring mechanism & $\begin{array}{l}\text { Monitoring and evaluation tools to } \\
\text { measure performance towards the } \\
\text { objectives of the strategy } \\
\text { Effective functioning of entrepreneurial } \\
\text { discovery process } \\
\text { Actions necessary to improve national or } \\
\text { regional research and innovation } \\
\text { systems } \\
\text { Actions to manage industrial transition } \\
\text { Measures for international collaboration }\end{array}$ \\
\hline
\end{tabular}

Source: Based on REGULATION (EU) No 1303/2013 (on the left) and the proposal for the new regulation $\operatorname{COM}(2018) 375$ final (on the right).

tion and the common framework provisions defined compulsory steps to build a strong evidence base and the continuous involvement of relevant stakeholders in 2013. This conditionality, known as 'smart specialisation', had far-reaching consequences: in cases of non-compliance, the European Commission could suspend funds for research, technological development and innovation. It triggered a policy learning process across the whole continent (Foray, 2015). Some leading scholars and practitioners described it as an 'ambitious experiment' (Sabel and Kuznetsov, 2017, p. 52). The concept is also part of the current proposal for the EU multiannual budget 2021-2027, where it is one of several 'enabling conditions'. Table 1.1 compares the fulfilment criteria for the current and proposed conditions. The new proposal prescribes in more detail which aspects are of particular relevance for a successful economic transformation. Instead of the original strengths, weaknesses, opportunities, threats (SWOT) 
analysis, an up-to-date analysis of bottlenecks for innovation diffusion is now demanded, with a special emphasis on digitalisation. Furthermore, the required monitoring mechanism is described in greater detail, including 'evaluation tools to measure performance towards the objectives of the strategy'. Data requirements are now even more ambitious, since the proposal explicitly calls for measures to manage industrial transition and foster international collaboration. In the proposed regulation the European Commission continuously monitors compliance and can suspend funds in case of non-fulfilment at any time. The need for high-quality data and quantitative methods to make sense of those data has increased.

This European concept of place-based innovation policy has met interest globally in Eastern Europe, Africa, the United States (US), Latin America and Australia (Dosso et al., 2018; Wilson, 2016; Radosevic and Ciampi Stancova, 2018; Kleibrink and Matusiak, 2018; Aranguren et al., 2014; Wessner and Howell, 2018; Office of the Economic Development Board, 2018; Kleibrink et al., 2017). The World Bank, the United Nations and OECD are either supporting countries with their effort to develop smart specialisation or contributing to its conceptual development (World Bank, 2016; OECD, 2014; UN IATT, 2019). International demand for localised data and analyses is on the rise.

The use of data and quantitative analysis is not only about comparing numbers. It is meant to convey a narrative that is able to engage a broader set of actors in the strategy's transformational agenda both within and outside the respective territory (Kleibrink and Gianelle, 2016; Mendez, 2013; Kleibrink and Magro, 2018). Two examples from Austria and Germany illustrate these two functions. The regional government of Lower Austria collects and organises relevant data on regional economic and innovation policy in a comprehensive yet concise balanced scorecard that allows for detailed and timely analytical monitoring. ${ }^{5}$ For assessing its position in comparison to other German and European regions, the government of Baden-Württemberg resorts to its own tailor-made innovation index which supports a robust narrative on innovation leadership in Europe, together with a sound analysis of innovation performance dynamics. ${ }^{6}$

Another more prominent example is from the US. In terms of advocacy, the Silicon Valley region in California has long been at the forefront of innovation communities worldwide. The multi-stakeholder organisation

5 See Interreg project KNOW-HUB for more information, http://www.knowhub.eu/blog/application-of-the-balanced-scorecard-methodology-in-lower-austrias-economic-and-innovation-policy.html.

6 For the Innovation Index 2018, see https://www.statistik-bw.de/Presse/Press emitteilungen/2018291. 
Silicon Valley Joint Venture has been publishing an index of the broader socio-economic developments in the region since 1995. This index aggregates 26 indicators of trends in Silicon Valley's economy and quality of life, reported on an annual basis (Saxenian and Dabby, 2004). Over time, this index has been increasingly tailored to stakeholder needs, and has contributed to a feeling of joint ownership in a region that is otherwise very much characterised by competition and individual achievements. In fact, it supported a narrative that framed policy and business debates by pinpointing gaps where action was required.

The outcome of the new conceptual approaches and of the new quantitative methods to treat data and information is a quantitative mapping of the degree of innovation capacities, of innovation priorities and of local conditions guaranteeing the success of local innovative policies. For a meaningful discussion with stakeholders, quantitative mapping is valuable as it provides the evidence and facts for an informed dialogue. This way of proceeding is an important one, since it informs stakeholders and policymakers of the necessary conditions. However, this all has to be reinforced by qualitative interpretations, not treated in this book.

\subsection{STRUCTURE OF THE BOOK}

The book is structured around two complementary parts. Part I contains methods and data that allow an understanding to be gained of the industrial fabric of territories on which innovation should be anchored. In fact, knowing all the relevant puzzle pieces of a territory's economic fabric is an essential first step for any strategic policy support. It is also a precondition for having informed dialogues and discussions with stakeholders, be they firms, associations, research institutes or universities.

Three chapters develop such a theme. Chapter 2, by Henning Kroll, presents a method with which to map economic specialisation. The chapter puts forward the idea that, according to EC guidelines and much early literature, the main rationale of smart specialisation activities is to provide innovation strategies for economic transformation. During the first period of its promotion, however, many strategies instead focused on research, and their monitoring on traditional STI indicators. Such analyses, however, do not necessarily provide a good indication for economic transformation, as in most regions outside leading clusters, scientific and economic activities remain structurally disconnected. Hence, future smart specialisation strategy monitoring needs to focus more on the state of local economies and their potential interfaces with science. This chapter suggests a process to achieve such monitoring. 
Chapter 3, by Frank van Oort, Nicola Cortinovis, Teodora Dogaru and Jeroen van Haaren, introduces the concepts of related variety and relatedness in the European Union, and discusses how this links to the entrepreneurial search process and innovative structural change in regional contexts. Throughout the chapter, the authors argue that although relatedness is a key element for supporting place-based innovation processes and policies, their interdependence and functioning requires more attention in both scientific and policy circles. The authors illustrate this by presenting new empirical research which puts skill-relatedness on the local (sub-regional) map of the Netherlands. The patterns of mapped relatedness are linked to policy implications at the local and regional level, and show that diversification strategies may be more complex to actively pursue when they have to comply with existing entrepreneurial, educational, industrial organisation, infrastructural and social network conditions.

Chapter 4, by Giovanni Mandras and Andrea Conte, deals with the phenomenon of global value chains (GVCs), representing networks of production and trade across countries, and therefore the complex industrial fabric of a global and interconnected world economy. In recent years, in fact, GVCs have become the new paradigm for the production of goods and services since production is increasingly internationally integrated. GVCs are directly identifiable by domestic exports, and indirectly by those regions that provide intermediate inputs to final exporting regions. Considering that trade in intermediate inputs accounts for two-thirds of international trade, a complete analysis of the magnitude of both direct and indirect contributions is needed to assess the position of regions and the degree of their participation in different types of GVCs, such as European value chains (EVCs), where the deepening of the European single market has fostered the process of economic integration.

Part II of the book deals with the mapping of regional innovation and the territorial conditions that favour innovation activities. Chapter 5, by Roberta Capello and Camilla Lenzi, provides a taxonomy of innovative regions that can be a useful policy tool to support fully decentralised regional innovation policy approaches, such as the smart specialisation strategy, so as to mitigate the multiple risks arising from the implementation of innovation policies. The chapter presents the most recent taxonomy of innovative regions, produced through a scientific effort based on the overcoming of several limitations that characterised the existing taxonomies. The chapter also demonstrates how the regional innovation pattern taxonomy, as it is called, is useful for suggesting innovation strategies specific to each group of innovative regions, which are aimed at the reinforcement and upgrading of the existing regional innovation mode. 
Chapter 6, by Hugo Hollanders and Monika Matusiak, presents a method to identify smart specialisation priority domains through an economic analysis that is able to highlight economic specialisations using detailed industry-level data on employment, value added, wages and exports. A second step involves the identification of the innovation potential of these preliminary priority domains by implementing an innovation potential mapping exercise. Mapping the innovation potential of regions should move from a generic and horizontal view of innovativeness, embodied in questions such as: 'What is the share of innovative companies in the national/regional economy?', to a more granular picture.

Chapter 7, by Susana Franco, Carlo Gianelle, Alexander Kleibrink and Asier Murciego, starts from the idea that innovation policy is inherently a highly experimental endeavour. In an increasingly complex, intertwined, fast-changing and uncertain world, policy-makers pursuing public policy innovations in support of economic development need to engage in a systematic process of policy learning. Benchmarking with peers is a powerful learning channel in regional innovation policy, provided that the identification of suitable peer regions is based on similarity in the structural dimensions influencing innovation policy. While several regional benchmarking methodologies and toolsets are currently available, regions are most often chosen for comparison based either solely on innovation and economic performance measures, paying insufficient attention to the context in which performance is or can be achieved, or on a mix of variables of different nature not suitable for supporting effective learning. To overcome those limitations, the chapter proposes a methodology to identify peer regions in the European Union focused on similarity in innovation-relevant structural characteristics. A novel database is presented covering all European Union regions, and a full matrix of regional pairwise distances resulting from the aggregation of several dimensions is constructed. The chapter ends by discussing selected cases and the related policy implications for the design and implementation of regional innovation policy.

Finally, Chapter 8, by Enric Fuster, Francesco A. Massucci and Monika Matusiak, focuses on new methods that can be used at the interface of science and policy for the identification of the localised domains of specialisation in science and technology. The authors explore semantic methodologies which, by analysing the textual content of science and innovation-related documents (such as policy and project descriptions, scientific publications, patents, clinical trials) go beyond classifications, allowing emergent topics and domains to be identified, as well as mapping and benchmarking the local capabilities in specific domains of interest. 


\section{REFERENCES}

Amin, A. and N. Thrift (1994), Globalization, Institutions and Regional Development in Europe, Oxford: Oxford University Press.

Aranguren, M.J., S. Franco and J.R. Wilson (2014), 'Conectando Estrategias de Especialización Inteligente y Clústeres: ¿Un Reto Clave Para América Latina?’, in Red Interamericana de Competitividad (ed.), Señales de Competitividad de Las Américas 2014, Washington, DC: Organization of American States, pp. 38-42.

Asheim, B. (2012), 'The Changing Role of Learning Regions in the Globalizing Knowledge Economy: A Theoretical Re-Examination', Regional Studies, 46 (8), 993-1004. https://doi.org/10.1080/00343404.2011.607805.

Barca, F. (2009), 'An Agenda for a Reformed Cohesion Policy: A PlaceBased Approach to Meeting European Union Challenges and Expectations', Independent Report, prepared at the request of Danuta Hübner, EU Commissioner for Regional Policy.

Borrás, S. (2011), 'Policy Learning and Organizational Capacities in Innovation Policies', Science and Public Policy, 38 (9), 725-734. https://doi.org/10.3152/030 $234211 X 13070021633323$.

Borrás, S. and J. Jordana (2016), 'When Regional Innovation Policies Meet Policy Rationales and Evidence: A Plea for Policy Analysis', CIRCLE Papers in Innovation Studies, no. 2016/12. http://wp.circle.lu.se/upload/CIRCLE/work ingpapers/201612_Borras_Jordana.pdf.

Boschma, R. (2005), 'Proximity and Innovation: A Critical Assessment', Regional Studies, 39 (1), 61-74.

Boschma, R. (2014), 'Constructing Regional Advantage and Smart Specialisation: Comparison of Two European Policy Concepts', Scienze Regionali, 13 (1), 51-68.

Boschma, R. (2017), 'Relatedness as Driver of Regional Diversification: A Research Agenda', Regional Studies, 51 (3), 351-364. https://doi.org/10.1080/00 343404.2016 .1254767$.

Boschma, R. and S. Iammarino (2009), 'Related Variety, Trade Linkages, and Regional Growth in Italy', Economic Geography, 85 (3), 289-311.

Boschma, R., A. Minondo and M. Navarro (2012), 'Related Variety and Regional Growth in Spain', Papers in Regional Science, 91 (2), 241-256.

Boyer, C. (1986), Dreaming the Rational City: The Myth of American City Planning, Cambridge, MA, USA and London, UK: MIT Press. https://www. amazon.de/Dreaming-Rational-City-American-Planning/dp/0262521113.

Camagni, R. and R. Capello (2013), 'Regional Innovation Patterns and the EU Regional Policy Reform: Towards Smart Innovation Policies', Growth and Change, 44 (2), 355-389.

Camagni, R. and R. Capello (2020), 'Contributions by Italian scholars to regional science', Papers in Regional Science, 99 (2), 359-388, DOI: 10.1111/pirs.12510.

Camagni, R., R. Capello and C. Lenzi (2014), 'A Territorial Taxonomy of Innovative Regions and the European Regional Policy Reform: Smart Innovation Policies', Scienze Regionali - Italian Journal of Regional Science, 13 (1), 69-106.

Capello, R. (2019), 'Theories of Innovation in Space: Path-breaking Achievements in Regional Science', in R. Capello and P. Nijkamp (eds), Handbook of Regional Growth and Development Theories, 2nd edn, Cheltenham, UK and Northampton, MA, USA: Edward Elgar Publishing, pp. 240-456. 
Capello, R. and H. Kroll (2016), 'From Theory to Practice in Smart Specialization Strategy: Emerging Limits and Possible Future Trajectories', European Planning Studies, 24 (8), 1393-1406.

Capello, R. and C. Lenzi (2013), 'Territorial Patterns of Innovation in Europe: A Taxonomy of Innovative Regions', Annals of Regional Science, 51 (1), 119-154.

Charles, D.R., C. Nauwelaers, B. Mouton and D. Bradley (2000), 'Assessment of the Regional Innovation and Technology Transfer Strategies and Infrastructures (RITTS) Scheme', Final Evaluation Report, Newcastle upon Tyne: CURDS (University of Newcastle) and MERIT (University of Maastricht) with PAIR and OIR.

Cooke, P. (2014), 'Systems of Innovation and the Learning Region', in M.M. Fischer and P. Nijkamp (eds), Handbook of Regional Science, Berlin and Heidelberg: Springer, pp.457-474. http://link.springer.com/10.1007/978-3-642-23430-9_28.

Dosso, M., A. Kleibrink and M. Matusiak (2018), 'Smart Specialisation in SubSaharan Africa: Opportunities and Challenges', in F. Pazisnewende Kabore, W.G. Park and S. Kati-Coulibaly (eds), Proceedings of EAI International Conference on Technology, $R \& D$, Education and Economy for Africa, Côte d'Ivoire, Abidjan, pp. 67-74.

Edgerton, D. (2004), 'The Linear Model did not Exist: Reflections on the History and Historiography of Science and Research in Industry in the Twentieth Century', in K. Grandin, N. Worms and S. Widmalm (eds), The Science Industry Nexus, Sagamore Beach, MA: Science History Publications, pp. 31-57.

European Commission (2007), 'Innovative Strategies and Actions: Results from 15 Years of Regional Experimentation', Brussels: Directorate-General Regional Policy.

Foray, D. (2009), 'Understanding Smart Specialisation', in D. Pontikakis, D. Kyriakou and R. van Bavel (eds), The Question of $R \& D$ Specialisation, Brussels: JRC, European Commission, Directorate General for Research, pp. 19-28.

Foray, D. (2015), Smart Specialisation: Opportunities and Challenges for Regional Innovation Policy, Abingdon, UK and New York, USA: Routledge.

Foray, D., P. David and B. Hall (2009), 'Smart Specialisation - the Concept', Knowledge Economists Policy Brief, no. 9.

Foray, D., P. David and B. Hall (2011), 'Smart Specialisation: From Academic Idea toPolitical Instrument', MTEI working paper, Lausanne.

Freeman, C. and L. Soete (1997), The Economics of Industrial Innovation, 3rd edn, Cambridge, MA: MIT Press.

Frenken, K., F.G. van Oort and T. Verburg (2007), 'Related Variety, Unrelated Variety and Regional Economic Growth', Regional Studies, 41 (5), 685-697.

Giannitsis, T. (2009), 'Technology and Specialization: Strategies, Options, Risks', Knowledge Economists Policy Brief, no. 8.

Hausmann, R. and D. Rodrik (2003), 'Economic Development as Self-Discovery', Journal of Development Economics, 72 (2), 603-633.

Iacobucci, D. and E. Guzzini(2016), 'Relatedness and Connectivity in Technological Domains: The "Missing Links" in S3 Design and Implementation', European Planning Studies, 24 (8), 1511-1526.

Iammarino, S., A. Rodriguez-Pose and M. Storper (2019), 'Regional Inequality in Europe: Evidence, Theory and Policy Implications', Journal of Economic Geography, 19 (2), 273-298. https://doi.org/10.1093/jeg/lby021.

Kleibrink, A. and C. Gianelle (2016), 'Monitoring Innovation Strategies: 
Co-Creating Sustainable Policy Cycles Together with Stakeholders', in D. Kyriakou, M.P. Martinez, I. Periáñez-Forte and A. Rainoldi (eds), Governing Smart Specialisation, Abingdon, UK and New York, USA: Routledge.

Kleibrink, A. and E. Magro (2018), 'The Making of Responsive Innovation Policies: Varieties of Evidence and Their Contestation in the Basque Country', Palgrave Communications, 4 (74). https://www.nature.com/articles/s41599-0180136-2.

Kleibrink, A. and J. Mateos (2017), 'Searching for Local Economic Development and Innovation: A Review of Mapping Methodologies to Support Policymaking', in B. Huang, K. Cao and E.A. Silva (eds), Reference Module in Earth Systems and Environmental Sciences, Amsterdam, the Netherlands; Oxford, UK; Waltham, MA, USA: Elsevier, pp. 59-68. https://doi.org/10.1016/ B978-0-12-409548-9.09674-3.

Kleibrink, A. and M. Matusiak (eds) (2018), Supporting an Innovation Agenda for the Western Balkans: Tools and Methodologies, Luxembourg: Publications Office of the European Union.

Kleibrink, A., P. Larédo and S. Philipp (2017), Promoting Innovation in Transition Countries: A Trajectory for Smart Specialisation, JRC Science for Policy Report, Luxembourg: Publications Office of the European Union.

Lundvall, B.-A. (1992), National Systems of Innovation: Toward a Theory of Innovation and Interactive Learning, London: Pinter. http://dx.doi.org/10.7135/ UPO9781843318903.

Lundvall, B.-Å. and B. Johnson (1994), 'The Learning Economy', Journal of Industry Studies, 1 (2), 23-42.

Mendez, C. (2013), 'The Post-2013 Reform of EU Cohesion Policy and the PlaceBased Narrative', Journal of European Public Policy, 20 (5), 639-659. https://doi. org/10.1080/13501763.2012.736733.

Morgan, K. (1997), 'The Learning Region: Institutions, Innovation and Regional Renewal', Regional Studies, 31 (5), 491-503. https://doi.org/10.1080/0034340975 0132289.

Nooteboom, B. (2000), Learning and Innovation in Organizations and Economies, Oxford: Oxford University Press.

North, D.C. (1990), Institutions, Institutional Change and Economic Performance, Cambridge: Cambridge University Press.

OECD (2014), Innovation-Driven Growth in Regions: The Role of Smart Specialisation, Paris: OECD Publishing. https://www.oecd.org/sti/inno/smart specialisation.htm.

OECD (2016), Regions at a Glance 2016, Paris: OECD Publishing.

Office of the Economic Development Board (2018), 'Smart Specialisation: Insights for a Future Industry Policy', Adelaide: Economic Development Board South Australia and Department of State Development.

Ohmae, K. (1993), 'The Rise of the Region State', Foreign Affairs, 72 (2), 78-87.

Piore, M. and C. Sabel (1984), The Second Industrial Divide: Possibilities For Prosperity, New York: Basic Books.

Porter, M.E. (2003), 'The Economic Performance of Regions', Regional Studies, 37 (6-7), 549-578. https://doi.org/10.1080/0034340032000108688.

Radosevic, S. and K. Ciampi Stancova (2018), 'Internationalising Smart Specialisation: Assessment and Issues in the Case of EU New Member States', Journal of the Knowledge Economy, 9 (1), 263-293. https://doi.org/10.1007/s131 32-015-0339-3. 
Rodríguez-Pose, A. (2018), 'Commentary: The Revenge of the Places That Don't Matter (and What to Do About It)', Cambridge Journal of Regions, Economy and Society. https://doi.org/10.1093/cjres/rsx024.

Sabel, C.F. and Y. Kuznetsov (2017), 'Managing Self-Discovery: Diagnostic Monitoring of a Portfolio of Projects and Programs', in S. Radosevic, A. Curaj, R. Gheorghiu, L. Andreescu and I. Wade (eds), Advances in the Theory and Practice of Smart Specialization, London and Oxford, UK; Cambridge, MA and San Diego, CA, USA: Academic Press, pp. 51-72.

Saxenian, A. and N.C. Dabby (2004), 'Creating and Sustaining Regional Collaboration in Silicon Valley? The Case of Joint Venture: Silicon Valley', Working Paper 2004-05, Institute of Urban and Regional Development, University of California at Berkeley.

Socintec and Inno (2005), 'Ex-Post Evaluation of the RIS, RTTs and RISI ERDF Innovative Actions for the Period 1994-99', Final Synthesis Report to the European Commission.

Tödtling, F. and M. Trippl (2005), 'One Size Fits All? Towards a Differentiated Regional Innovation Policy Approach', Research Policy, 34 (8), 1203-1219. https://doi.org/10.1016/j.respol.2005.01.018.

UN IATT (2019), 'A Guidebook for the Preparation of STI for SDGs Roadmaps: An Input to the Fourth STI Forum, New York', New York: United Nations InterAgency Task Team on Science, Technology and Innovation for the SDGs (IATT). https://sustainabledevelopment.un.org/content/documents/22724Guidebook_ STI_for_SDG_Roadmaps_Draft_for_STI_Forum.pdf.

Wessner, C.W. and T.R. Howell (2018), 'Smart Specialization in US Regional Policy: Successes, Setbacks and Best Practices', Background paper for an OECD/EC Workshop, 15 October, workshop series 'Broadening Innovation Policy: New Insights for Regions and Cities', Paris.

Wilson, B. (2016), 'Smart Specialization and Innovation: A View from Beyond Europe', in A. Nikina, J. Piqué and L. Sanz (eds), Areas of Innovation in a Global World: Concept and Practice, Malaga: International Association of Science Parks and Areas of Innovation, pp. 1-7.

World Bank (2016), Toward an Innovative Poland: The Entrepreneurial Discovery Process and Business Needs Analysis, Washington, DC: World Bank. 